\title{
The Anglo-Norman Bible Stories in Ms Brit. Libr. Harley 2253
}

\author{
Julia C. Szirmai ${ }^{1}$ (D) \\ Published online: 15 November 2018 \\ (c) The Author(s) 2018
}

\begin{abstract}
The Anglo-Norman Bible Stories, contained in Ms Brit. Libr. Harley 2253, an Old Testament narrative including Genesis, Exodus and Numbers, is of interest to the study of Old French bible adaptations, in that its contents present parallels (canonical and apocryphal) to some of these texts. This may aid us in narrowing down the sources used by their compilers. Since the first mention of the text in 1883, the Bible Stories have found an editor in 2015. Whereas the text is now available (Fein et al. 2015), there has not been made a thorough study of the contents (beside the one by Wilshere in Forum Mod Lang Stud 24:78-89, 1988; Thompson, in: Fein (ed) Studies in the harley manuscript. The scribes, contents, and social contexts of British Library MS Harley 2253, Michigan, 2000), including not only the 'Bibles intégrales' like those compiled by Herman de Valenciennes, Jean Malkaraume and Macé de la Charité, but also a more recently published Old Testament poem, the Fragment de la Genèse en vers. It is the latter text that drew our attention to the Anglo-Norman Bible Stories, both texts presenting a number of similarities that deserve to be looked at in more detail.
\end{abstract}

Keywords Anglo-Norman Bible Stories · Brit. Libr. Harley 2253 · Translationsadaptations of the Bible in Old French - Un Fragment de la Genèse en vers . Herman de Valenciennes · Peter Comestor's Historia Scholastica

In 2015 Susanna Fein and her co-workers published the contents of Ms Brit. Libr. Harley 2253 with the intention of showing the structure of the compilation of the manuscript and the distribution of the material in a socio-cultural and linguistic context (ed. and trans. Fein et al. 2015).

One of the texts, contained in the manuscript, the Anglo-Norman Bible Stories (ff. $92 \mathrm{v}-105 \mathrm{r}$ ), is of particular interest to the Old French Bible adaptations in that

Julia C. Szirmai

J.C.Szirmai@hum.leidenuniv.nl

1 Department of French Language and Culture, Universiteit Leiden, Postbus 9515,

2300 RA Leiden, The Netherlands 
it shows parallels to some of these translations of the Vulgate, in language and in content.

Resuming very briefly the story of Jacob, the Bible Stories then concentrate on his son Joseph, including legendary material (Genesis), and continue with a long narrative on the dwelling of the Jewish people in the desert (Exodus and Numbers).

The Bible Stories were first mentioned by P. Meyer in his review of S. Berger's La Bible française au Moyen Age (Berger 1884); to the texts related by Berger, he adds "quelques textes bibliques français, de médiocre importance [...]", including the biblical stories: "une paraphrase assez libre d'une partie de la Genèse et de l'Exode, qui semble la mise en prose d'un texte en vers" (Meyer 1888, p. 140). He cites the beginning and the end.

J. Vising, in 1923, situates the text in the twelfth century and, like Meyer, doesn't mention the fact that the Bible Stories contain also some passages from Numbers. He follows Meyer in stating that the text is a "prose version of a biblical poem" (Vising 1923, p. 42).

D. Legge seems to be of the same opinion, but places the text in the fourteenth century (Legge 1963, p. 180).

A facsimile edition of the Bible Stories has been published by N.R. Ker in 1965 (Ker 1965).

An interesting article on the Anglo-Norman Bible Stories was written by A.D. Wilshere in 1988 ${ }^{1}$; he compared the language of the Bible Stories with that of Fouke le Fitz Warin and found a large number of similarities between the two texts. He also situates the text in the fourteenth century. Ruth Dean describes our text as: "Old Testament stories from Genesis, Exodus, Numbers. [...] expanded from Peter Comestor's Historia Scholastica and other sources" (Dean 1999, p. 252, no. 71). She dates the Stories between 1330 and 1340.

In 2000, John J. Thompson dedicated an important chapter to the Bible Stories and insists, not only on the disposition of the materiel by the scribe, but also on the motivation of the translator of the Bible Stories in his choice of certain biblical passages (Thompson 2000; see also Fein 2010).

When preparing the edition of Un Fragment de la Genèse en vers du Ms. Harley 3775 (Szirmai 2005), we noticed a number of similarities between our Fragment and the Bible Stories, not only concerning the language, ${ }^{2}$ but also the contents.

The Anglo-Norman Bible Stories have never been edited until they drew the attention of Susanna Fein's team. ${ }^{3}$ This may be due to the fact that the text remains close to the Vulgate, and offers less legendary material, less curious details and less exegetical commentaries than other biblical poems like the Bibles of Herman de

\footnotetext{
${ }^{1}$ Wilshere (1988, pp. 78-89). Wilshere also directed the doctoral thesis of S. Merrick, who made a detailed analysis of the syntax of the Bible Stories (Merrick 1976). We express our gratitude towards the Library of Waterloo University for providing us with a copy of this thesis.

${ }^{2}$ Expressions like "lele gent", the queen who starts to "braier" and "crire", etc. See Wilshere (1988, p. $85)$ and Szirmai (2005, pp. 25 sqq.).

${ }^{3}$ Fein et al. (2015, III, pp. 19-78). See also Fein (2010). The thesis of Merrick (1976) has not been published.
} 
Valenciennes, Macé de La Charité, Jean Malkaraume and the Bible anonyme (BnF 763) (Cf. Bonnard 1884; Smeets 1968, 1970).

As the edition of Fein is restricted to the publication of the text and some minimal (philological) notes (Fein et al. 2015, III, pp. 367-368), we believe the article we present may shed some more light at the merits of the scribe and at the contents of the text. We will examine the narrative following the order of the Bible books used. $^{4}$

\section{Genesis}

In the opening lines of the Bible Stories, the author points at the "diverses estoyres" his readers ("Seigneurs") are already familiar with (from Adam to Jacob) and that he will, therefore, not relate. In his brief resume of the story of Jacob and Esau, he lists the sons of Jacob, stating erroneously that Leah, not Rachel (his "fames fraunches") ${ }^{5}$ is the mother of Joseph and Benjamin, though correcting his mistake later on (v. 19). ${ }^{6}$

Neglecting the narrative on Juda and Thamar, the author then focuses on the story of Joseph (vv. 18-264), that is of particular interest as to the sources the Bible Stories may have relied on, other than the Vulgate and Comestor's Historia Scholastica (Sylwan 2005; Ginson and Froehlich 1992; cf. Morey 1993).. The Joseph story is highlighted in many vernacular texts, particularly in Li Romanz de Dieu et de sa mère by Herman de Valenciennes (Spiele 1975) and in the Bible anonyme (Szirmai 1985).

Though following rather closely the Vulgate text (Colunga and Turrado 1982 and Fillion 1921-24), the author of the Bible Stories provides a number of non- canonical details in the Genesis section.

Jacob sends Joseph to see his brothers who take care of the cattle, for, as the author adds, in those days the people lived from their flock and the shepherds protected their animals firmly from lions and other wild beasts, an assertion he may have found in Josephus' Antiquities. ${ }^{7}$ After the brothers have thrown Joseph in the well, Ruben goes to visit his "bestes", a detail we find in Comestor's Historia, as well as in the Antiquities by Flavius Josephus, and which the Bible Stories share with other Old French texts. ${ }^{8}$

\footnotetext{
${ }^{4}$ We retain the numbering of the lines in Fein et al. (2015).

5 Cf. Saint Isidore, PL 83, 261: "Itaque duae sunt uxores Jacob liberae".

${ }^{6}$ Curious mistake also in the Bible de Geufroi de Paris, where Leah is considered the younger sister (v. 1895).

7 Blatt (1958, II, ch. 2.2). Cf. Comestor, PL 198, 1126A.

8 Comestor, PL 198, 1126A; Blatt (1958, II, ch. 2.2). See the Bibles of Macé de La Charité and of Malkaraume, the Genèse d'Evrat, and l'Estoire de Joseph, though not in Herman de Valenciennes. The beginning of the Joseph story is lacking in the Fragment de la Genèse. In the Bible Stories, Judas, after proposing to sell Joseph, adds: "ou plus jamés ne orroms de ly" (vv. 41-42). In Geufroi's Bible we read: "Ja mais jour n'en orrons parler" (v. 2042).
} 
That also goes for the fact that it is Pharaoh's queen, not Potiphar's wife, who tries to seduce Joseph, ${ }^{9}$ a version of the story that goes back to texts like The Testament of the Twelve Patriarchs (second or third century BC) and to Latin and vernacular narratives of the Middle Ages. ${ }^{10}$ We find this version also in the Bible des sept estaz. du monde by Geufroi de Paris and in Herman's Bible. In the Bible Stories we see a mixture of the Vulgate version and the legendary one, Joseph being sold to Potiphar who, on account of his beauty, gives him to Pharaoh. We note the same combination of facts in the Bible anonyme (BnF fr. 763) and in the Bible of Malkaraume (Smeets 1978). Wilshere (1988) seems to consider the fact that the queen "comença braier e crire" [began to shout and scream] (v. 59) a particular feature of the Bible Stories ${ }^{11}$; however, the lady also cries out in the Genèse by Evrat, in the Bible anonyme, in the Estoire de Joseph (Sass 1906) and in Un Fragment de la Genèse. The Harley author puts a certain emphasis on the episode of the unfaithful wife: when Joseph reveals himself to his brothers, telling them how he came to power in Egypt, he adds: "Et si je avoy fet le consail la reyne, Dieu ne me ust soffert avoir enjoyee cest honour" [And had I followed the queen's councel, God would not have permitted me to enjoy this honor] (vv. 184-185). ${ }^{12}$

Some elements in the Joseph story seem to point to a connection with the Fragment de la Genèse en vers. In the Bibles Stories the Egyptians are qualified as "payenz", a detail we did not find in other Bible adaptations. Whereas Wilshere attributed this qualification to its author, it seems to parallel the description of Potiphar ("paen grant") in the Fragment de la Genèse (Wilshere 1988, p. 83; Szirmai 2005, p. 76).

The author's expansion on Aseneth, Joseph's bride, and her rich father is not found in other Old French translations, and considered by Wilshere to be the authors "own additions", but matches the description in the Fragment de la Genèse (Szirmai 2005, p. 76; Thompson 2000, p. 283, n. 29).

So is the mention of the river Jordan being "molt [...] loinz" de Canaan in the Bible Stories (v. 117) and the words uttered by Jacob speaking of the chaff floating on the river in the Fragment: "Enseur seez vent de loynz" (v. 2098) (Wilshere 1988, p. 84; Szirmai 2005, p. 84; cf. Faverty 1928, pp. 79-104). This legend, by which Jacob was aware that there was food in Egypt, is also found in Herman's Bible, in the Bible by Geufroi de Paris, in the English poems Iacob and Iosep and the Cursor Mundi, and in the Fragment de la Genèse.

In 2005 we were able to establish the fact that the Joseph story in the Fragment de la Genèse represents an unknown version of Herman's Bible (Szirmai 2005, introduction). Thompson also noticed a number of parallels between the Bible stories and Herman's text, although they "are never close enough to enable us to identify

\footnotetext{
9 Wilshere (1988, p. 79) apparently ignored the existence of this legendary version of the story in other texts. Cf. also Thompson (2000, p. 282).

10 See for example the German poem Judith and the Middle English Iacob and Iosep (Murdoch 2003, pp. 149-174).

11 Gen. XXXIX, 14 stating only: 'vocavit ad se homines domus suae'.

12 Only in Herman's Bible there is a later reference to Pharaoh's wife (v. 1918).
} 
Herman as that likely intermediary [...]" between the Bible Stories and their Latin sources (i.e. Vulgate and Comestor) (Thompson 2000, p. 282). Concerning one of those instances where the Bible Stories deviate from the Vulgate and may have used another source, he found another "interesting similarity" between the Bible Stories and Herman's text: the brothers of Joseph kneel before him when they first see him; in the Fragment de la Genèse also the brothers "a ses peez chaierunt" (v. 2119). ${ }^{13}$

For other features the redactor of Ms 2253 seems to rely on the Historia Scholastica: Jacob's change of name into 'Israel' is accompanied by an etymology, the latter name being "taunt a entendre come 'cely qe vist Dieu" and explained thus: "quar is id est vir, ra id est videns, el id est Deum, et sic Israel id est vir videns Deum" (vv. 230-233), a gloss that Comestor bases on Josephus. ${ }^{14}$ He will come back to this Latin source in his narrative on Exodus and Numbers. Sometimes he depends seemingly on his memory only: thus he confuses Joseph's children (saying that Manassen is the younger one $)^{15}$ and states erroneously that Jacob died at the age of 157 years. ${ }^{16}$

So far, we can conclude that the Bible Stories have made use of Comestor's Historia Scholastica and of the Jewish Antiquities by Flavius Josephus. Furthermore, we note the influence of vernacular French texts such as the Genèse by Evrat and the Bibles by Herman de Valenciennes and Jean Malkaraume, in a lesser degree of the Bible by Geufroi de Paris and the Bible anonyme.

Especially noteworthy are the parallels between the Bible Stories and the Fragment de la Genèse en vers: thus we find, exclusively in the Bible Stories and the latter text, the details about the Egyptiens being "payenz" and the description of the father of Aseneth.

\section{Exodus}

The Bible Stories, turning to Exodus, then relate the hardship of the Jewish people under a new Pharaoh and the infancy of Moses, including a very succinct reference to the legend of Pharaoh's crown (see Nobel 1996a, b, I,72-73; cf. Wilshere 1988, p. 82), in which the child Moses, being saved by Pharaoh's daughter, 1 day sits in the lap of his grandfather and pulls the crown of his head. Pharaoh, having been warned in a dream that a Jewish child will ruin his kingdom, wants to kill the child. Instead they make little Moses do a test, whereby he burns his tongue, being the reason for his later speech impediment. A story to be found also in other Old French texts and for which the main source seems to be the Historia Scholastica. ${ }^{17}$

The author confuses the episodes of Moses slaying the Egyptian and that of his encounter with the two Hebrews (Ex. II, 11-14.) (Wilshere 1988, p. 79). Listing the

\footnotetext{
13 Thompson (2000, p. 283). Cf. Boers (2002), La Genèse d'Evrat: 'tuit l'aorent, en terre enclin' (v. 16646).

14 Comestor, PL 198, 1121.

15 It is curious to note the same error in Evrat (v. 17677) and Malkaraume (vv. 4388 ss).

16 Cf. Evrat, v. 18180.

17 Amongst others in some versions of Herman's Bible. See PL 198, 1144A/B.
} 
tribes living in the Holy Land, he has probably also relied on Comestor who, contrary to Ex. III, 17, includes the Girgashite.

More important, he also confuses the order of the plagues sent upon Egypt, beginning with the fourth ("mousches" [flies]), the fifth ("mortalite de bestes" [death of the livestock]), the sixth ("maladie de cors" [boils]) and the seventh ("grisil" [thunder and hail]), returning to the second ("reynes" [frogs]) and the third ("verms" [gnats]), ending with the tenth ("mortalité de hommes" [death of the Firstborn]), omitting those of the water changed into blood (one), the locusts (eighth) and the darkness (ninth). He then resumes the ten plagues in a mnemonic (vv. 412-413), for which he may have found an example in Comestor $^{18}$ :

II Sanguis, rana, culex, musce, pecus, ulcera, grando

Brucus, caligo, mors optinuere necando

After narrating the exodus from Egypt, passing over "Pascua", he dwells at length on the crossing of the desert. At times, the author refers directly to the Latin text: the women rejoicing after the crossing of the Red Sea sing: "Cantemus Domino, gloriose, et caetera" (v. 443); wondering about the heavenly food, the people exclaim: "Manna, manna, quid est hoc? Manna est interjectio admirantis" (vv. 458-459). ${ }^{19}$ In the complaint of the people about their food ("lur alme nausea [...]"; v. 745) we clearly see the influence of the Latin: "anima nostra nauseat [...]" (Num. XXI, 5).

The battle with Amalec is rendered faithfully to the Vulgate. According to the author it is Jesus who descends from Mount Sinai to administer his precepts to the people of Israel (v. 483). ${ }^{20}$ The author turns to Numbers for a description of the tabernacle before relating the episode of the Golden Veal, expanding Ex. XXXII, 19-20 by having the people play all sorts of instruments, besides singing and dancing (vv. 527-28). ${ }^{21}$

The Ten Commandments are not specified. Like Herman de Valenciennes, the Harley redactor merely states that Moses receives the Tables, written by God.

As in other adaptations of the Vulgate (Loh 1912), Moses "ad deus cornes en sa teste" when he descends a second time from Mount Sinai that scare off the people (vv. 586-588). Here the author does not follow the correct explanation of "cornuta" (Ex. XXXIV, 29) by Comestor. ${ }^{22}$

As the Fragment de la Genèse breaks off in the middle of the Joseph story, we have no means to compare it with the Bible Stories. Still, we can ascertain that the author of the latter text has in common with other vernacular Bible texts the legend of the child Moses and Pharao's crown, not only found in some versions of Herman's

\footnotetext{
18 Comestor, PL 198, 1149D.

19 Cf. Blatt (1958, III, 1): "sic erat ergo cibus ille divinus et inopinabilis". In the Bible Stories, Moses and Aaron pray to God after the rebellion of Datan and Abyron, adressing Him as Fortisme Deus. Later on (v. 757) the people, after having been given a well, sing: "Ascendat puteus, et cetera".

${ }^{20}$ Cf. Moldenhauer (1914, p. 75): "Moyses se descause, Jhesuscrist l'araisna”.

21 An expansion we also find in Macé de La Charté's Bible (Smeets 1967), vv. 5164 sqq.

22 Comestor, PL 198, 1192.
} 
Bible, ${ }^{23}$ but also in the Bibles by Macé and Malkaraume, le Poème Anglo-normand sur l'Ancien Testament (Nobel 1996) and the Bible d'Acre (Nobel 2006).

The author, however, doesn't seem to follow Herman, who makes no mention of the ten plagues send upon Egypt.

\section{Numbers}

The author omitting the book of Leviticus, a rather tedious account of the numbers of the twelve tribes opens the section on Numbers (vv. 592 sqq.). ${ }^{24}$ At line 598 a marginal note in red ink ("Nota") marks the beginning of the numbering of the tribes, which mark is repeated at line 624. The number of the tribe of the Levites, responsible for the tabernacle and the ark, is indicated by another marginal mark in red ink at line 627 ("Levy").

The scribe faithfully relates the events at the place of the "espernement" [Burning], where God punished the people for their grumbling against Him, and the rain of quails at the "Sepulcres de Coveytise" [Graves of Covetousness]. He then recounts the leprosy of Miriam and the exploring of Canaan, not mentioning the grapes that Caleb and Joshua brought back from the Promised Land.

In lines 727-35, the author, referring to the Bible, gives a rather personal commentary on the animal and other sacrifices of the "payens Judeux" [pagan Jews]. All that has now changed into Christian sacrifices, he says, the "eglise a Christienz" from now on replacing the synagogue. The redactor seems to be referring to Comestor's Historia Scholastica in stating that "cest escrit fut fet" one hundred thousand one hundred and thirty years after the death of Christ. ${ }^{25}$

The narrative then recounts the treason of Korah, Dathan and Abiram, who were, says the author, "suppris de le deable" [deceived by the Devil] (v. 742), and the flowering rod of Aaron, whereupon follows a long list of the laws to be maintained by the tribe of Levy, stating charmingly that their priests shall have custody of all first things coming from the womb of "femme ou autre beste" (v. 802). ${ }^{26}$

After relating the battles with the pagan kings, and God forbidding Moses and Aaron to enter the Promised Land, the author gives a rather detailed account of the story of the prophet Balaam and the talking ass.

The Bible Stories end with the crime of fornication by Zimri and Cozbi and a recommendation for further reading in Numbers.

The final words of the Harley redactor are: "E qe bon fyn avera la joie de ciel ne perdra" [And he who has a good end will not lose the joy of heaven] (v. 986).

\footnotetext{
${ }^{23}$ Paris, BnF fr. 2162 and Pierpont Morgan Library Ms 526. Cf. BnF fr. 6447, which may be a prose version of Herman's Bible (Meyer 1896).

24 For an explanation of the choices of the author, see Thompson (2000, p. 283).

25 Cf. Wilshere (1988, p. 80) and Thompson (2000, pp. 284-285). For other details on the text, see Wilshere (1988).

26 Translated in Fein et al. (2015) with political correctness as "woman or else beast".
} 
Thompson may stress the focus of the author of the Bible Stories on the numbering of the tribes of Israel (especially on the Levites), ${ }^{27}$ as well as on the rights and tasks of the priests, but this is not exceptional. The author of the Bible anonyme, for example, elaborates on these points too (vv. 5712-5832).

The most remarkable feature of the Harley scribe in the Numbers section is his personal view on the pagan sacrifices of the Israelites (Num. XV), mentioned above. Apart from defending the Christian rites, he explains magnanimously the fact that the Israelites also made sculptures and pictures: "quar peynture c'est lyvre a ceux qe ne ount conoissaunce de lettre" [for painting is a book for those who do not have understanding of letters] (vv. 730-731), a digression that follows the teachings of Gregory the Great and the monastic traditions of the twelfth and thirteenth centuries (see Deremble 2008, p. 80).

The question remains to know what kind of text we are dealing with. Wilshere (1988) doesn't give the compiler much credit as a narrator and states that the interest of the Bible Stories "is hardly literary". The text ending rather abruptly, the narrative in Harley 2253 may be, as Thompson proposes in view of other biblical adaptations, "an experimental item" (Thompson 2000, p. 281), inspired by personal motivations of the scribe.

\section{Conclusion}

Until now, the Anglo-Norman Bible Stories have been studied from different perspectives by A. D. Wilshere and J. J. Thompson.

Wilshere (1988), discussing the sources the author may have relied on, focuses on the Vulgate and Peter Comestor's Historia Scholastica, but ignores possible influences of vernacular texts, such as the "Bibles integrales" by Herman de Valenciennes, Malkaraume and Macé de La Charité, and the Bible anonyme. The interest of the Bible Stories for him resides in the linguistic features of the text that convinced him that the Harley scribe may also have been the author of the romance Fouke le Fits Waryn.

Thompson (2000), on the other hand, concentrates on the disposition of the materiel by the scribes (A and B), but also on the motivation of the translator (scribe B) of the Bible Stories in his choice of certain biblical passages, marked by the rubrication in the manuscript, highlighting the genealogy of the tribes of Israel and the duties of the Levites (see also Fein 2010). Thompson (2000) does point to similarities with vernacular texts like Herman's Bible (though especially in the section of scribe A, that deals with the New Testament) and the poem Iacob and Iosep.

Relating to the content (and linguistic details), however, both studies ignore the parallels we found in Un Fragment de la Genèse en vers (Ms Harley 3775), that seems to represent an unknown version of Herman'Bible.

In the present article our aim was to demonstrate that the Bible Stories rely not only on Latin sources. Not all the correspondences between the Bible Stories and Un

27 The marginal notes in the manuscript seem to confirm this. 
Fragment de la Genèse are based on Herman's Bible, which leads us to believe that the redactor of the Bible Stories has used an intermediary text that not only made use of Herman, but also of sources the Bible Stories have in common with Un Fragment de la Genèse.

Although we are dealing with two rather short Old Testament texts, the existence of striking similarities between the two as far as language and content is concerned, may contribute to further understanding of the relationship between Old French Bible adaptations.

Open Access This article is distributed under the terms of the Creative Commons Attribution 4.0 International License (http://creativecommons.org/licenses/by/4.0/), which permits unrestricted use, distribution, and reproduction in any medium, provided you give appropriate credit to the original author(s) and the source, provide a link to the Creative Commons license, and indicate if changes were made.

\section{References}

Berger, S. (1884). La Bible française au Moyen Age. Étude sur les plus anciennes versions de la Bible écrites en prose de langue d'oül, Paris (repr. Genève: Slatkine Reprintsm, 1967).

Blatt, F. (Ed.). (1958). Antiquités juives. The Latin Josephus: Introduction and text. The Antiquities, Acta Jutlandica 30, 1; Humanistic Series 44, Aarhus \& Copenhague.

Boers, W. (Ed.). (2002). La Genèse d'Evrat. Brive la Gaillarde: Ver luisant.

Bonnard, J. (1884). Les Traductions de la Bible en vers français au Moyen Âge. Paris: Imprimerie nationale.

Colunga, A. O. P., \& Turrado, L. (Eds.). (1982). Biblia sacra iuxta Vulgatam clementinam, sexta editio. Madrid: Biblioteca de Autores Cristianos.

Dean, R. (1999). Anglo-Norman literature. A guide to texts and manuscripts, London: Anglo-Norman Text Society.

Deremble, J.-P. (2008). Fulbert and Theophile, l'art de la prédication. Le IVe sermon de la fête dela Nativité de Marie. In M. Rouche (Ed.), Fulbert de Chartres, précurseur de l'Europe médiévale?. Paris: PU Paris Sorbonne.

Faverty, F. E. (1928). Legends of Joseph in Old and Middle English. PMLA, 43, 79-104.

Fein, S. (2010). Compilation and purpose in MS Harley 2253. In Medieval texts and cultures of northern Europe. Essays in manuscript geography. Brepols, Turnhout.

Fein, S., Raybin, D. \& Ziolkowski, J. (Ed. and trans.) (2015). The complete Harley 2253 manuscript, 3 vols, TEAMS, Middle English Text Series. Kalamazoo: Medieval Institute Publications, Western Michigan University.

Fillion, L.Cl. (1921-24). La Sainte Bible commentée d'après la Vulgate et les textes originaux, Paris: Letouzey et Ané.

Geufroi de Paris (forthcoming). La Bible des sept estaz du monde, edition is in preparation by J. C. Szirmai.

Gibson, M. T. \& Froehlich, K. (Intr.). (1992). Biblia latina cum Glossa Ordinaria. Facsimile Reprint of the Editio Princeps, Adolph Rusch of Strasbourg 1480/81. Turnhout: Brepols.

Ker, N. R. (1965). Facsimile of British Museum MS. Harley 2253, EETS o.s. 255. London: Oxford University Press.

Legge, D. (1963). Anglo-Norman literature and its background. Oxford: Oxford University Press.

Loh, H. (Ed.). (1912). Histoires tirées de l’Ancien Testament. Münster: Universitätsdruckerei Johannes Bredt.

Merrick, S. (1976).Transcription and slot-order analysis of article 71 of BM Harley 2253, Unpublished M.A. thesis. (University of Waterloo).

Meyer, P. (1888). Review of S. Berger, La Bible française au Moyen Age. Romania 17, 121-44.

Meyer, P. (1896). Notice du Ms. Bibl. Nat. fr. 6447. Notices et Extraits de la Bibliothèque Nationale et autres bibliothèques, $\mathrm{XXXV}, 2^{\mathrm{e}}$ partie. Paris : Imprimerie nationale. 
Moldenhauer, O. (1914). La Bible von Herman de Valenciennes, Teil II (Greifswald). Greifswald: Hans Adler.

Morey, J. H. (1993). Peter Comestor, biblical paraphrase, and the medieval popular Bible. Speculum, $68(1), 6-35$.

Murdoch, B. (2003). The medieval popular Bible. Oxford: Brewer.

Nobel, P. (Ed.). (1996). Poème anglo-normand sur l'Ancien Testament, 2 vols. Paris: Champion.

Nobel, P. (Ed.). (2006). La Bible d'Acre. Genèse et Exode. Besançon: Presses universitaires de Franche-Comté.

Sass, E. (1906). L'estoire de Joseph. Berlin: Dresde.

Smeets, J.-R. (Ed.). (1967). La Bible de Macé de La Charité. Genèse, Exode. Leiden: Universitaire Pers.

Smeets, J.R. (1968, 1970). Les traductions, adaptations et paraphrases de la Bible en vers, Grundriss der Romanischen Literaturen des Mitelalters VI/1, 48-57, VI/2, Heidelberg: Carl Winter.

Smeets, J.-R. (Ed.). (1978). La Bible de Jehan Malkaraume, 2 vols. Assen/Amsterdam: van Gorcum.

Spiele, I. (Ed.). (1975). Li Romanz de Dieu et de sa Mere d'Herman de Valenciennes. Leiden: Leiden Universitaire Pers.

Sylwan, A. (Ed.). (2005). Petri Comestoris Scolastica Historia. Liber Genesis. Turnhout: Brepols.

Szirmai, J. C. (Ed.). (1985). La Bible anonyme du Ms. Paris B.N.F. fr. 763. Amsterdam: Rodopi.

Szirmai, J. C. (Ed.). (2005). Un fragment de la Genèse en vers (fin XIIIe-début XIVe siècle). Genève: Droz.

Thompson, J. J. (2000). Frankis rimes here I redd,/ Communlik in ilk[a] sted... : The French Bible Stories in Harley 2253 in S. Fein (Ed.), Studies in the Harley Manuscript. The scribes, contents, and social contexts of British Library MS Harley 2253. Michigan: Medieval Institute Publications.

Vising, J. (1923). Anglo-Norman language and literature. London: Oxford University Press.

Wilshere, A. D. (1988). The Anglo-Norman Bible Stories in MS Harley 2253. Forum for Modern Language Studies, 24, 78-89. 